\title{
Flowering and Fruiting Eco-physiology of Calotropis procera (Ait.) W.T. Ait., and importance of Gas in Fruit dehiscence.
}

\author{
Hasan El-Tantawy \\ Botany Department, Faculty of Sicence, Menoufia University \\ Shebin El-Kom, Egypt
} El-Tantawy H. 2000. Flowering and Fruiting Eco-physiology of Calotropis procera (Ait.) W.T. Ait, and
importance of Gas in Fruit dehiscence. Taeckholmia 20(1): 69-80.

\begin{abstract}
The phenology and ecology of flowers, fruits and mechanism of fruit dehiscence have been studied.
Usher Calotropis procera produces flowers throughout the year with a peak in the early dry season (summer). The number of flowers was very high reaching of 959 flowers/tree, while the production of fruits was very low (22 fruit/tree). Each seed is covered at one tapered end by parachute-like silky hairs of about $3.16 \pm 0.4$ $\mathrm{cm}$. in length. It is possible to use the seed hairs as source for natural fibers in arid and semiarid regions. Fruits are dehiscent by gas pressure $(140.75 \pm 24.4 \mathrm{~mm} \mathrm{Hg})$. It was found that the gas occupies about $70 \%$ of whole volume of fruit. The gas content $\left(\mathrm{N}_{2} \& \mathrm{O}_{2}\right)$ expands with increased temperature causing a pressure on the pericarp and leading to fruit dehiscence.
\end{abstract}

Key words: Calotropis procera, dehiscence, flowering, fruiting.

\section{Introduction}

Calotropis procera (Ait.) W.T. Ait., (Asclepiadaceae) is a common perennial small desert tree widely distributed in the Egyptian deserts (Täckholm, 1974). On the global scale, the species is distributed from the west of Africa to the arid zones of India (Zafimahoval, 1981 - Alwadi \& Abul fatih, 1996). Phenological characters of this species represent an adaptation to the hot, dry and wet seasons in the eastern regions. Arroyo et al. (1981), stated that ecologists have only recently paid attention to the relationships between phenological patterns, vegetative growth strategies and reproductive characteristics. Most of the desert species produce flowers during or after rainy season, with subsequent fruiting. Kassas (1966), reported that some desert plant perennials continue to flower and set fruits all the year round. A number of studies have been carried out on Calotropis procera at the ecological, physiological and phytochemical levels (Malik \& Gupta, 1976; Cheam, 1984; El-Monayeri et al.; 1986; Datta, 1988; El-Sharkawi et al., 1989; Badiani et al., 1990). Seiber et al. (1982), reported that cardinolide analyses are presented for a range of species in the Asclepiadaceae, including some known to be toxic to vertebrates and certain insects. Relative high contents were found in leaves and latex of five species. including Calotropis procera. The plant (called Usher in Arabic) is not important commercially, and not used as forage because of its milky poisonous sap, but it is used in folk medicine for the treatment of various human ailments (Watt \& Breyer-Brandwijk, 1962 - Osborn, 1968); such as the relife of rheumatic pain and swelling (Abulfatih 1987). Al-Robai, et al. (1998), reported that CGs contents of the Usher latex may be influenced by ecological factors such as temperature, humidity and rainfall. Corbet (1998), reported that the degree of self-incompatibility (cross pollination gave greater seed and fruit numbers than self- pollination), and pollinator limitation (hand cross- pollination gave 
greater seed and fruit numbers than open pollination) as well as resource limitation. However aspects of flowering fruiting and the mechanism of fruit dehiscence has not been investigated before.

Field observations showed that Calotropis procera produces and bear flowers nearly throughout the year but a peak of fruit production was observed during the hot / dry season. The number of flowers was very high when compared with the number of fruits. The fruit opens or splits along the ventral suture. It seems that the gas content of the inflated fruits participates in their dehiscence. Touching or slight pressure of the mature fruit results in their dehiscence. Consequently, the following questions were raised; why this species gives a high number of flowers but produces low number of fruits, and what is the nature and importance of the gases inside the fruit and its role in fruit dehiscence.

\section{Materials and Methods}

Phenological observations on flowering were carried out on naturally growing populations of Calotropis procera at Suez area, in the Eastern Desert of Egypt. The number of flowers as well as the number of ripe and unripe fruits were monthly recorded for several individuals from January to November for three successive years. Mature fruits were chosen at random and obtained from a population in mid August (hot/dry season). Phenological characters were studied on mature fruits varying in shape, colour and size.

\section{Determination of Gas Volume}

A group of fruits were collected and covered by a smear of vaseline, to avoid loss of the gas through evaporation, and transported to the laboratory as soon as possible. The gas content was collected and measured in an inverted graduated glass cylinder by water displacement as shown in Fig. (1). In order to elucidate dehiscence, some fruits on different Usher plants were labeled and punctured by small cork porer without any damage in fruits to release their gas content.

\section{Determination of Gas Pressure and Components}

Gas pressure inside fruits was determined by Sphygmo-manometer which is often used for measuring the low pressure, while the gas components were detected and determined by gas chromatography (GC) using Perkin Elmer apparatus.

\section{Determination of Gas Pressure Along the Ventral Suture}

Based on the relation between the force, area and pressure, the pressure along the ventral suture of the fruits was calculated. Some mature fruits with different colour and sizes were collected. Three or more strips $(1 \mathrm{x} 4 \mathrm{~cm}$ and thickness $0.4 \mathrm{~mm})$ were splitted along the ventral suture of each fruit, as illustrated in Fig. (2).

A strip was hanged or held from one side and weights (gm) were added gradually on the other side until the strip was subjected to splitting at the suture. The weight was recorded and the following formula was adopted to estimate the pressure required for fruit dehiscence. 


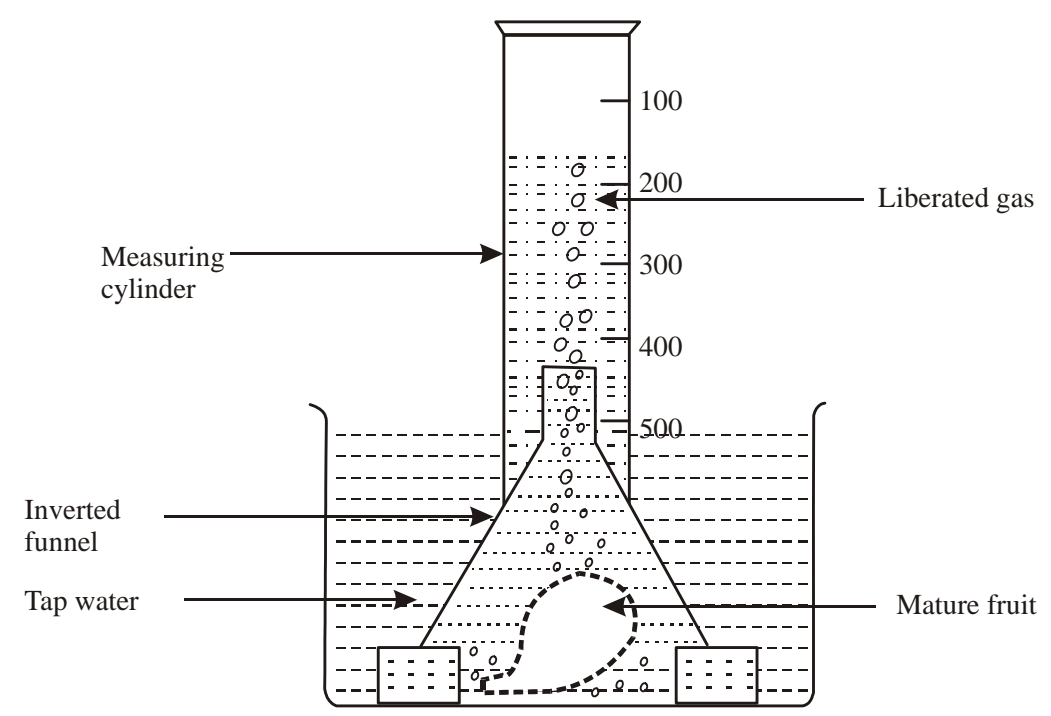

Fig. (1): Collection and measuring the volume of gas liberated from the fruit of Calotropis. Procera.

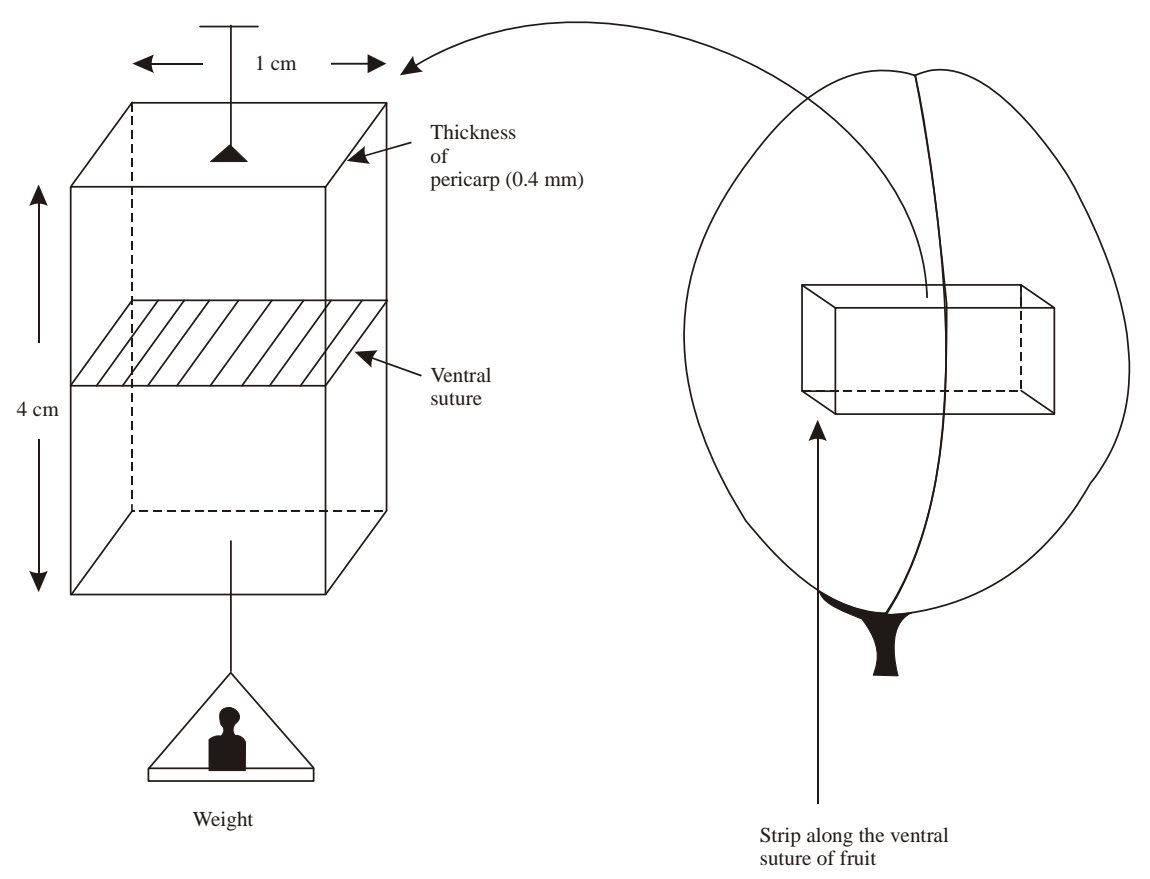

Fig. (2): Measuring the tensile strength of the pericarp at the ventral suture. 


$$
\text { Pressure }=\text { Force } / \text { Area, } \frac{\text { Newton }}{(\text { meter })^{2}} \text { Or P }=\mathrm{F} / \mathrm{A} \frac{(N)}{(m)^{2}}
$$

Where $\mathrm{F}=$ mass (weights or burden) $\mathrm{x}$ constant gravity

$$
\mathrm{F}=\mathrm{mg} \quad \mathrm{N}=\text { Newton } \quad \mathrm{A}=\text { Area of strip }(\mathrm{m})^{2}
$$

After calculation, the following formula was applied to estimate the pressure along the ventral suture

$$
1 \mathrm{~atm}=760 \mathrm{~mm} \mathrm{Hg}=1.013 \times 10^{5} \mathrm{~N} / \mathrm{m}^{2}
$$

\section{Results}

Records of the environmental conditions (Fig.3) shows that the study area is located in a hyper arid region with mild rainy winter and hot summer. The average monthly temperature of coldest month (January) was $15.6^{\circ} \mathrm{C}$, while the average monthly temperature of highest temperature (August) was $29.2^{\circ} \mathrm{C}$. Rainfall was scanty and irregular. The dry period covered about 8 months. The average annual was $14.7 \mathrm{~mm}$. The relative humidity was high all over the year with minimum value of $42 \%$ in May and maximum value of $58 \%$ in November. Wind velocity was higher during winter months in summer. Nevertheless, it is evident that Usher (Calotropis procera) thrives under severe condition producing flowers and fruits.

\section{Phenology and Fruits Characters}

Calotropis procera produces flowers nearly all year round. The number of flowers increase after the rainfall with the increasing air temperature. The maximum number was observed during May. The average number of flowers per individual tree was very high at the end of the wet season and reached 959 flowers / tree. The number of ripened fruits were very low and ranged between 4-18 fruits/individual tree. From the data illustrated in (Fig. 4), each tree bears the lowest number of flowers in February while the highest number of flowers occurs in May. After pollination and swelling of ovaries, the rate of fruit growth increased with increasing temperature (hot/dry season). Generally, the yearly production of flowers per individual was very high in comparison with the low number of fruits.

The volume of the fruits was relatively large. The fruit contains a spongy tissue $\left(172.3 \mathrm{~cm}^{3}\right)$ which occupies about $70 \%$ of the whole volume of the fruit $(245.8 \pm 8.35$ $\mathrm{cm}^{3}$ ). The length of fruit varied from one to another; it ranged between 9 and $13.1 \mathrm{~cm}$ (mean, $11.7 \pm 1.4$ ), while the fruit periphery reached $23.4 \mathrm{~cm} \pm 2.2$ (Table 1). On maturation, the colour of the fruit changed from dark green to green or yellowish green. 

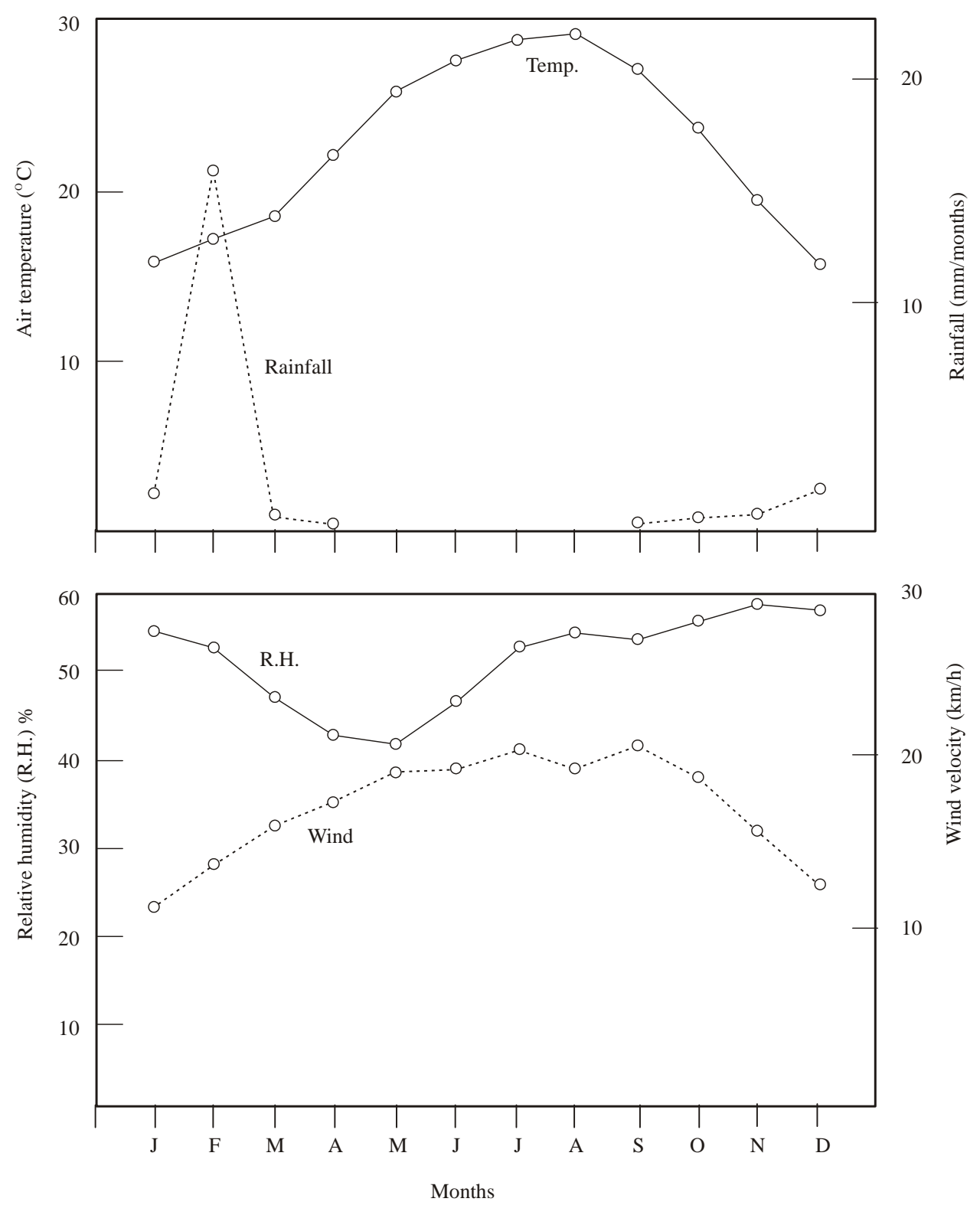

Fig. 3: Mean monthly values of air temperature $\left({ }^{\circ} \mathrm{C}\right)$, rainfall (mm.), relative humidity (\%), and wind velocity $(\mathrm{km} / \mathrm{h})$ at Suez area in the eastern desert of Egypt. 


\section{Role of Gas in Fruit Dehiscence}

Some fruits were randomly chosen and labeled on different branches of several trees, the spongy layer was punctured to liberate or release the gas, leaving the fruits on trees without gas effect. After two weeks, it was found that the fruits were shrinked and dried up and remained without splitting or dehiscence.

\section{Gas pressure}

Gas pressure inside several fruits with different colour and size was measured. It was found that the gas pressure differed according to the volume of the spongy tissue and the degree of ripening. Low pressure (101 mm Hg) was detected in ripend fruits (yellowish green fruits), while small unripe fruits (deep green in colour) had the maximal value of

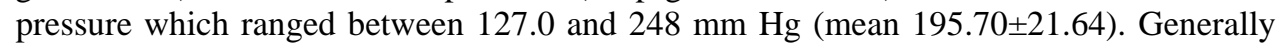
the pressure was found to be inversely proportional to the size of the fruit i.e. high pressure was recorded in small unripe fruits and low pressure in larger ripe fruits.

\section{Gas Components}

Gas chromatographic determination (Fig. 5) revealed that the gas components consist mainly of nitrogen (88\%) and oxygen (11\%). No other kinds of gases (such as ethane, methane, propane, etc...) were detected except oxygen and nitrogen with traces of carbon dioxide.

\section{Mechanism of Dehiscence}

The fruit is composed of a pair of follicles united to from one locule which contains many broadly ovate, flat tomentose seeds. At maturation, the gas which occupied about $70 \%$ of the whole volume of the fruit expanded with increased temperature causing a pressure on the pericarp and leading to fruit dehiscence or splitting from mid ventral suture causing exposure of seeds to external atmospheric factors. Dispersal was found to begin almost after one day of dehiscence, where the moisture content of the fruit decreased.

\section{Seed Dispersal}

Seeds were dispersed from mid summer (August) to the end of the dry season (October), depending on the degree of ripening, the moisture content of seeds and wind velocity in addition to other climatic factors. After dehiscence of fruits, seeds become exposed to external atmospheric factors and their colour changes from yellow to brown (Plate $1 \mathrm{~B}: 3$ ). Each seed is provided with a parachute-like structure of silky hairs which vary in length, approximately $3.16 \pm 0.4 \mathrm{~cm}$ (Table 1 ). The amount of silky hairs in mature fruit is variable and reaches $4.7 \pm 0.94 \mathrm{gm}$. Trials to obtain fibers from the fruits (unpublished data) indicate the possibility to use the "Usher" fruit as a source of fibers, particularly in arid and semiarid regions. 


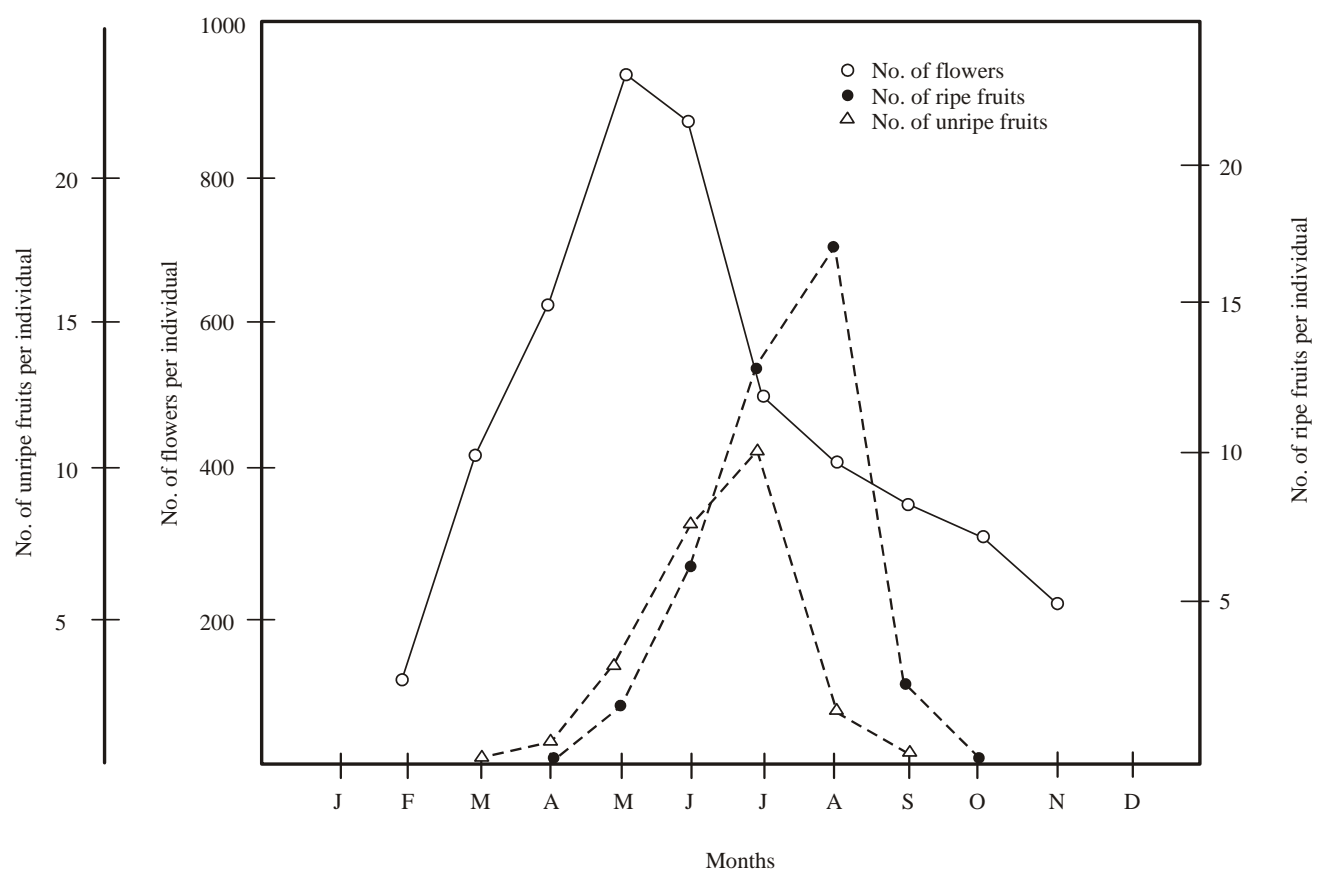

Fig. 4: Variation in the average number of flowers, unripe \& ripe fruits of $\boldsymbol{C}$. procera produced within one year.

\section{Discussion}

Flowering and fruiting of Calotropis procera can be helpful in describing the mechanism of fruit dehiscence, seed dispersal, seed production and flowering period. The present study showed that the Usher flowers are prevalent all year round, however, the peak of flowering lies only at the end of the growing wet season (spring). This phenomenon (flowering throughout the year) is rare in most plants (Kassas, 1966 and Frankle \& Opler, 1974).

Nevertheless, the peak of flowering in Usher may be due the high soil moisture content and moderate climatic factors during and immediately after the rainy season (Fig. 3). Additionally, pollination and fertilization takes place during the peak period of flowering ovaries which are swelling at this time. The pollination and fertilization in Asclepiadaceae is dependent on the presence of certain insects (Benson, 1959; Pandy, 1982), which may dominate at the early dry season. Also the sex ratios of pollinators play an important role in pollination and thereafter the fruit production (Paut et. al., 1982; Bawa \& Webb, 1983 and Jennersten et. al., 1988). Noteworthy to mention, that the number of fruits is very low when compared with the very high number of flowers. This may be attributed to the in sufficient number of pollinators or may possibly need a photothermal period which occurred in early and mid dry season. 
Table (1): Seed and fruit characteristics of Calotropis procera (Measurements were taken on individuals of $2 \mathrm{~m}$ high $\& 3 \mathrm{~m}$ crown diameter).

\begin{tabular}{|c|c|c|c|}
\hline${ }^{z_{N}}$ J० \% & $\begin{array}{l}0 \\
\infty \\
\infty\end{array}$ & +1 & ¿ே. \\
\hline $\mathrm{z}_{\mathrm{O}} \mathrm{fO} \%$ & g্ & +1 & $\overrightarrow{0}$ \\
\hline 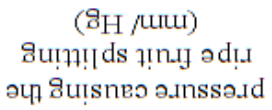 & \begin{tabular}{l}
$n$ \\
$\stackrel{n}{+}$ \\
\multirow{1}{*}{}
\end{tabular} & +1 & $\stackrel{+}{\stackrel{ \pm}{d}}$ \\
\hline 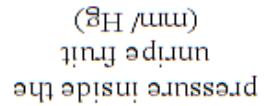 & $\begin{array}{l}\circ \\
\stackrel{2}{a} \\
\end{array}$ & +1 & $\stackrel{+}{\stackrel{ \pm}{d}}$ \\
\hline 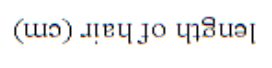 & $\begin{array}{l}\stackrel{ }{-1} \\
m\end{array}$ & +1 & $\stackrel{+}{\circ}$ \\
\hline 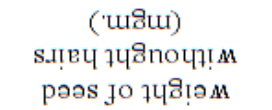 & 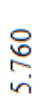 & +1 & $+\infty$ \\
\hline 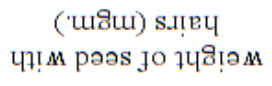 & $\begin{array}{l}\stackrel{0}{0} \\
0 \\
0\end{array}$ & +1 & ڤo \\
\hline 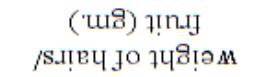 & 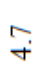 & +1 & ఫั \\
\hline 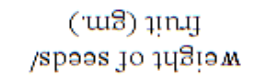 & $\begin{array}{l}\infty \\
\qquad \\
n\end{array}$ & +1 & ণั \\
\hline 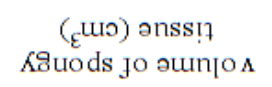 & $\stackrel{m}{N}$ & +1 & $\stackrel{\infty}{ \pm}$ \\
\hline 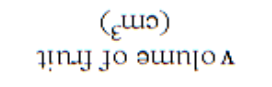 & 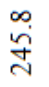 & +1 & $m$ \\
\hline (wo) & $n$ & +1 & $\stackrel{0}{\circ}$ \\
\hline 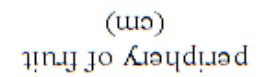 & ๙े & +1 & ָָ \\
\hline (wo) & $\exists$ & +1 & $\stackrel{\nabla}{\sim}$ \\
\hline 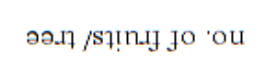 & $\underset{\sim}{\sim}$ & +1 & $\stackrel{0}{\circ}$ \\
\hline 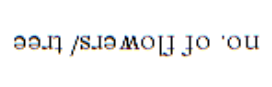 & $\begin{array}{l}\infty \\
\infty \\
\infty \\
\curvearrowleft\end{array}$ & +1 & $\stackrel{0}{n}$ \\
\hline
\end{tabular}


The chance of migration and the invasion power of a plant species depends upon the number of fruits and on seed production as well as on the total number of fertile seeds (Weaver \& Clements, 1983) and the establishment of seedling.

In a previous work (El Tantawy, 1989), it was found that the seeds of Calotropis procera is very efficient and the germination percentage reaches $90 \%$ or more under a wide range of environmental conditions (temperature, water stress, light and quality of light, salinity etc.). The high viability of seeds of Calotropis procera is to compensate the low rates of fruit and seed production.

Several suggestions have been reported to describe the mechism(s) of fruit dehiscence, however there is no report on the role and importance in fruit dehiscence. The present study showed that the gases $\left(\mathrm{N}_{2}\right.$ and $\left.\mathrm{O}_{2}\right)$ occupy about $70 \%$ of to total volume of the fruit of Calotropis procera. The punctured fruits failed completely to dihisce. It is believed that the accumulation of gases in fruit plays an essential role in fruit dehiscence. The present suggestion was substantiated with the fact the expansion of gases in response to the raise of temperature during hot and dry season leads to high pressure $(195.70+$ $21.64 \mathrm{~mm} \mathrm{Hg}$ ) inside the fruit which forces its dehiscence at the ventral suture.

Seed dispersal after splitting depends mainly on the reduction in its moisture content, and the reduction in its masses and sizes. The presence of the silky parachute like hairs on Calotropis procera seeds together with the small mass of the seed $(5.76 \pm 0.8 \mathrm{mg})$ are regarded as the major factors facilitating its wind dispersal (Platt \& Wels, 1977; Weaver \& Clments, 1983; Augspurger, 1986).

\section{References}

Abulfatih, H.A. (1987). Medicinal plants in southwestern Saudia Arabia. Economic Botany, 41 (3): $354-360$.

Alwadi, H.M. \& Abulfatih, H.A.(1996) Uniformity of morphological characteristics of Calotropis procera found at two altitudinal ranges, in Saudia Arabia. Arab Gulf J. Scient. Res, 14 (1):169 - 176.

Al-Robai, A.A., Abo-Khatwa, A.N. \& Jamal, Z.A. (1998). Toxicological Studies on the Latex of the Usher Plant Colotropis procera Ait. in Saudia Arabia. V. Seasonal variation of total cardiac glycosides in the Usher plant latex and in various tissues of the Usherhopper, Poekilocerus bufonius Klug. Arab Gulf J. Scient. Res., 16 (1):129 - 144.

Arroyo, M.T.K., Armesto, J.J. \& Villagam, C. (1981). Plant phenological patterns in the high Andean Cordillera of Central Chile. J. Ecol. 69:205-223.

Augspurger, C.K (1986). Morphology and dispersal of wind dispersed disperse of new tropical trees. Amer .J. Bot. 73(3):353-363.

Badiani, M., Blasli, M.G. de, Colognola, M. \& Artemli, F.(1990). Catalase, peroxidase and superoxide dismutase activities in seedings submitted to increasing water deficit. Agrochemica. 34(1-2): 90-102.

Bawa, K.S. and Webb, C.J. (1983). Floral vaiation and sexual differentiation in Muntingia calabura (Elaeocarpaceae), a species with hermaphrodite flowers. Evolution 37: 1271-1282.

Benson, L. (1959). Plant Classification : 103 \& 219. Heath and Company, Lexington, Massachusetts. 
Cheam, A.H. (1984). Allelopathy in buffel grass (Cenchrus ciliaris L.) l. Influence of buffel grass association on calotrope Calotropis procera (Ait). W.T. Ait. Australian weeds 3 (4): 133-136.

Corbet, S.A (1998). Fruit and seed production in relation to pollination and resources in blue bell. Hyacinthoides non - scripta 114: 349-360.

Datta, de.S.K. (1988). Ethane-pharmacognosy of Calotropis. Acta horticultura 188 A: 5559.

El-monayeri, M.O., Khafaga, O.A., Ahmed, A.M. \& El-Tantawy, H. (1986). Contribution to the chemical composition of plants belonging to various ecological groups in the Red Sea area. Desert inst. Bull., A.R.E. 36(2): 405-430.

El-Sharkawi, H.M., Farghl, A. \& Sayed, S.A. (1989). Interactive effects of water stress, temperature and nutrients in the seed germination of three desert plants .J. Arid Environ. 17 (3): 307-318.

El-Tantawy, H.(1989). Ecophysiology of seed germination and seedling establishment of Calotropis procera. J. Fac. of Education. 14: 583-605.

Frankle, H. G. B. \& Opler, p. A. (1974). Comparative phenological studies of trees in tropical wet and dry forests in the low land of Costa Rica. J. Ecol. 62: 881-919.

Jennersten, O., Berg, L. \& Lehman, C. (1988). Phenological difference in pollinator visitation, pollen deposition and seed set in the sticky catchfly, Visicaria vulgaris. J. Ecol. 76: 1111-1132.

Kassas, M. (1966) Plant life in desert. In: Hillis E.S., (ed.) Arid Lands:145-180. Methuen, London.

Malik, C.P. \& Gupta, S. C. (1979). Electrophoretic analysis of protein from pollen and pollen tubes of Calotropis procera. Indian J. Exp. biol. 14(6): 688-690.

Osborn, D.J. (1968). Notes on medicinal and other uses of plants in Egypt. Economic Botany 22: 165 - 177.

Pandy, B. P. (1982). Taxonomy of Angiosperms : 169. S. Shand \&Company Ltd, New Delhi.

Paut, D.D., Nautliyal, D.D. \& Chaturved, S.K. (1982). Pollination ecology of some Indian asclepiads. Phytochemistry. 32(4):302-313.

Platt, W.J. \& Wels, J.M. (1977). Resource partitioning and competition within a guild of fugative prairie. Amer. J. Bot. 68: 616-624

Sieber, J.N., Nelson, C. J. \& Lee, S.M. (1982). Cardinolides in the latex and leaves of seven Asclepias species and Calotropis procera. Phytochemistry . 21(9): 23432348.

Täckholm, V. (1974). Students’ Flora of Egypt, (ed. 2). Cairo University.

Watt, J.M. \& Breyer-Brandwijk, M.G. (1962). Medicinal and poisonous plants of southern and eastern Africa (2nd ed.). 1457. Livingstone. Edinburgh.

Weaver, J.E. \& Clements, F. E. (1983). Plant Ecology, Tata McGraw-Hill Publishing Company Ltd. New Delhi.

Zafimahoval, D.D. (1981). A Nigerian plant Calotropis procera, Asclepiadaceae. Ann. Univ. Abidjan ser. 17: 161-182. 
Fig. 5: Diagrammatic representation of gas chromatographic peaks of possible gases inside fruit of Calotropis. procera.

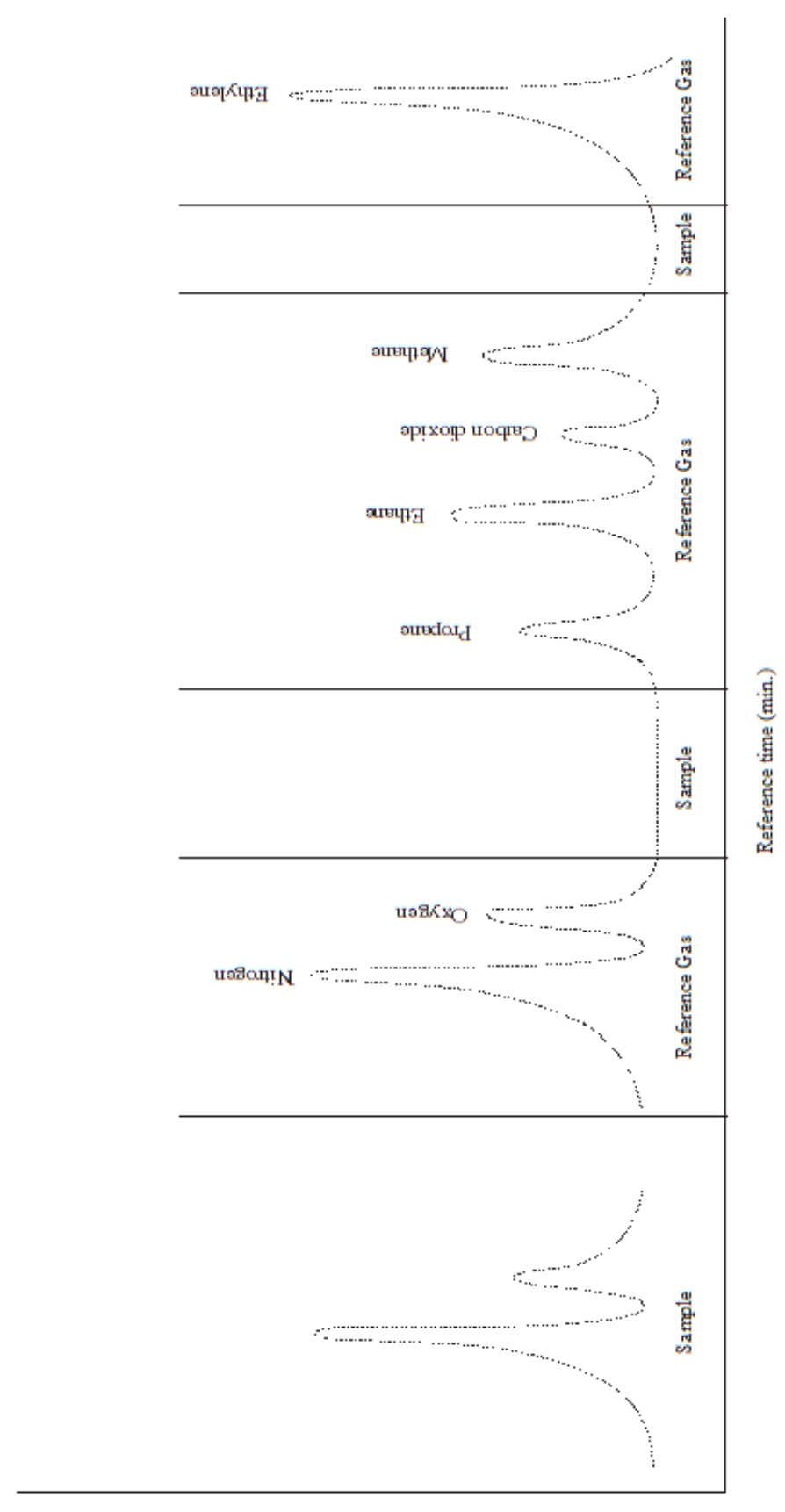

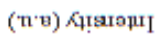




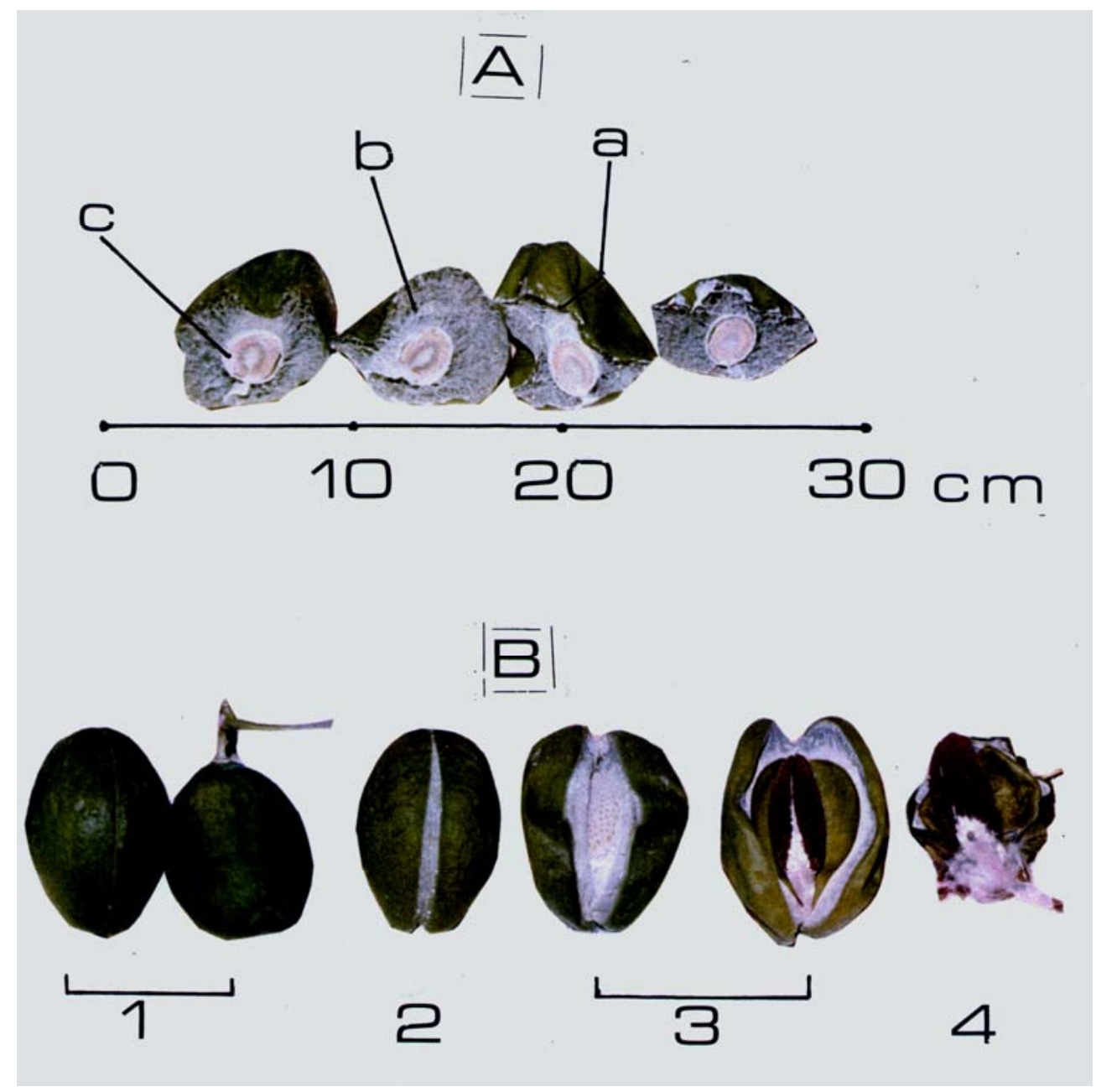

A- Cross section in mature fruits showing the different parts

a- Epicarp, b. Mesocarp (spongy tissue or gas tissue), c. Endocarp

B- Stages of fruit dehiscence

1. Mature fruit, 2. Partially opened fruit at the ventral suture,

3. Dehiscent fruit with exposed seeds at different stages of maturation,

4. Seed dispersal. 